\title{
A Soft Skills Experiment in an Industrial Engineering and Management Academic Course
}

\section{A Demonstration of how to Develop Soft Skills}

\author{
Klaas Stek \\ University of Twente, the Netherlands \\ Graz University of Technology, Austria
}

\begin{abstract}
Industrial firms increasingly concentrate on their core competences and outsource noncore activities, affecting the personal (soft) skills requirements of purchasing and supply chain management (PSM) personnel in their boundary-spanning roles. In parallel, machines take over processes but cannot replicate humans' soft skills such as creativity and strategic thinking. The literature shows that learning objectives in PSM courses in higher education are evaluated for not covering soft skills. Moreover, there is evidence that soft skills development is challenging. It is questionable which soft skills can be developed and which didactics are applicable. This study presents an educational soft skills experiment with IEM graduates, and it provides evidence that soft skills learning can effectively be introduced in existing courses. The graduates self-rated their competence levels of 36 soft skills before and after the course that provided soft skills workshops and a case study. In the first survey, "strategic thinking" ranked low and could be improved the most in the second survey.
\end{abstract}

Keywords: educational experiment, soft skills, strategic thinking, industrial engineering and management, business administration, purchasing and supply chain management, case study, constructive alignment

\section{INTRODUCTION}

\section{Preface}

In this chapter, the role of higher education lecturers in preparing the next generation of industrial engineering managers is addressed by presenting an active learning method for the training of (1) knowledge and theory, (2) professional and interpersonal skills, and (3) intrapersonal traits. It presents the results of an educational experiment in an academic master's course with students of Industrial Engineering and Management (IEM) and Business Administration (BA), more precisely, in the field of purchasing and supply chain management (PSM) which belongs to the domain of Operations Management.

The challenges of further digitalisation and the circular economy need to be addressed with technological advancement, which is the focus of this book. Technological 
advancement is a human effort and requires competent humans to combine hard skills ([technological] knowledge, theory and professional skills) and soft skills (interpersonal skills and intrapersonal traits or attitudes), as shown in this study.

The recommendation is to distinguish between (1) knowledge and theory, (2) professional and interpersonal skills, and (3) intrapersonal traits and to design for each of these three (I) intended learning outcomes, (II) didactical approaches and (III) assessment methods. This study distinguishes between hard and soft skills and found evidence in the literature that soft skills learning objectives are absent in academic (PSM) curricula. Therefore the following recommendation is to formalise soft skills learning objectives. Educators need to understand that soft skills cannot be assessed the same way as knowledge. For instance, to test the progress in soft skills, the students were evaluated with two surveys before and after a cognitive and soft skills training course in which they worked on a real-life case study in an experimental educational design.

\section{The Lack of Soft Skills in Higher Education}

The experiment in this chapter is performed in a PSM course. The importance of the PSM function in organisations increased in the past decades. Although make-or-buy decisionmaking leading to outsourcing has a long tradition in organisations and academic writings (Ammer, 1983; Gross, 1966; Jauch \& Wilson, 1979), from the 1990s, organisations increasingly started outsourcing non-core activities, meaning that those were not produced within the organisation but purchased from suppliers (Cousins, Lamming, Lawson, \& Squire, 2008; Luzzini \& Ronchi, 2016).

The significant increase of outsourcing by organisations is affected by political-economic, technological and demographic developments. From the 1980s, the political-economic systems have been affected by the trade tariffs elimination efforts of the GATT and WTO (Narlikar, 2003), which stimulated globalisation and led to increased global sourcing activities accelerated by the Chinese economic reform from the late 1970s (Logan, 2011). Organisations increasingly concentrated on their core competences, as underlined by Prahalad and Hamel (1990), and outsourced non-core activities. The outsourcing of noncore activities led to increased supplier management, supply chain management and strategic PSM decision-making, and the scope of PSM objectives (Luzzini \& Ronchi, 2016; Schoenherr, 2010).

As a result, PSM has shifted from an operational, transactional, and highly strategic function (e.g. Bals, Schulze, Kelly, \& Stek, 2019; Tassabehji \& Moorhouse, 2008). Bals et al. (2019) confirm the PSM function's strategic focus and point at the effects of the Internet-of-Things or the $4^{\text {th }}$ Industrial Revolution and "moving towards a circular economy and circular supply chains" (Bals et al., 2019, p. 10). In the $4^{\text {th }}$ Industrial Revolution affects PSM, or "Procurement 4.0," machine-to-machine communication will take over operational tasks (Bals et al., 2019) and is "influencing the digitisation of procurement and supply chains" (Bienhaus \& Haddud, 2018, p. 965). Moreover, it has led to another palette of required competences. i.e. a balanced mix of hard and soft skills, especially intrapersonal traits, like 'strategic thinking' (e.g. Bals et al., 2019) and 'creativity' (e.g. Kiratli, Rozemeijer, Hilken, de Ruyter, \& de Jong, 2016). 
There is evidence that formal learning objectives regarding soft skills, i.e. interpersonal human-to-human skills and intrapersonal character traits, are primarily absent in academic PSM courses and tracks (Birou, Lutz, \& Zsidisin, 2016; Stinenbosch, 2017; Wong, Grant, Allan, \& Jasiuvian, 2014). Bals et al. (2019) argue that PSM lecturers in higher education should introduce learning objectives that cover the context of future requirements caused by the challenges of sustainability and the Internet of Things. Nonetheless, Fawcett and Rutner (2014) have found that PSM higher education is "not evolving at the pace and in the way expected by professionals" (Fawcett \& Rutner, 2014, p. 181).

The literature on organisational knowledge and skills provides different taxonomies. A body of literature distinguishes between hard skills and soft skills (e.g. Andrews \& Higson, 2008; Bailly \& Léné, 2013; Heckman \& Kautz, 2012; Laker \& Powell, 2011). Heckman and Kautz (2012, p. 451) define soft skills as: "personality traits, goals, motivations, and preferences". Laker and Powell (2011, p. 113) distinguishes "hard-skills or technical training (working with equipment and software) and soft-skills training (interpersonal or intrapersonal focus)".

Thus, in higher education courses, a significant role is given to the transfers of knowledge and theory, and in parallel, academic courses are not equipped to apply those hard skills in practice, i.e. via the development of soft skills in the curricula. Ahmed, Fernando Capretz, Bouktif, and Campbell (2012) provided evidence that soft skills (i.e. interpersonal skills and intrapersonal traits) are as crucial as knowledge factors and professional skills (or hard skills) for professionals. Moreover, the lack of soft skills is more likely to be the reason for ending a labour relationship than a lack of knowledge (Ahmed et al., 2012). Employers highly value soft skills necessary to carry out professional tasks or hard skills (Ahmed et al., 2012).

Stek and Schiele (2021) provided quantitative evidence that soft skills are necessary but not sufficient conditions to carry out hard skills. The literature differentiates between "sufficient" or "necessary" conditions. Sufficient conditions lead to outcomes, whereas a necessary condition will prevent an effect from taking place (Van der Valk, Sumo, Dul, \& Schroeder, 2016). Therefore, Stek and Schiele's (2021) finding that soft skills are necessary conditions for hard skills execution means that the absence of soft skills predicts the absence of effectiveness in carrying out hard skills.

The increasing importance of intrapersonal character traits such as 'strategic thinking' and 'creativity' as proposed by Bals et al. (2019) and Kiratli et al. (2016), is in line with the findings Von der Gracht, Giunipero, and Schueller (2016). They researched future PSM skills of purchasers and foresaw existential threats in organisations. When in a "talent war", competitors recruit the most "creative and innovative minds" (Von der Gracht et al., 2016, p. 30). This finding is confirmed by Von der Gracht et al. (2018, p. 9), who found that machine-to-machine communication personnel must be "creative, productive and innovative" in the future era of machine-to-machine communication personnel. Hence, the right brainpower will be decisive in the age of the Internet-of-Things and artificial intelligence (AI): "To the extent that digital transformation is also transforming our society into a knowledge society, our economy could likewise change into a knowledge economy, or even into a 'human economy', where not only intellect but especially creativity, passion, character and team spirit will make the difference" (Von der Gracht et al., 2016, p. 10). 
The conclusion is that humans are distinct from machines since humans possess creative, inventive skills that machines lack. The issue of whether machines or Al can be 'creative' is countered by Du Sautoy (2019) in 'The Creativity Code: Art and Innovation in the Age of $A l^{\prime}$ with the understanding that instead of a replacement of human creativity by machines, Al will support and accelerate human creativity (Du Sautoy, 2019). Hence, the creativity and inventiveness of the human workforce will stay an essential factor.

Bals et al. (2019) underlined the importance of fully integrating all competences needed for developing PSM function into higher and professional education and industrial training programmes: knowledge, professional and interpersonal skills, and a substantial set of intrapersonal traits. Moreover, Bals et al. (2019) highlighted that student-centred teaching methods should replace traditional, frontal teacher-centred methods "as current training and teaching methods are not necessarily suitable for developing all types of competencies, and the pedagogy needs to be adapted to reflect these requirements" and suggest: "in-class training formats such as role-plays and the potential for online courses and more interactive formats, e.g. blended learning or flipped classroom approaches" (Bals et al., 2019, p. 11).

In general, the question is how PSM research could address the complexity of the $21^{\text {st }}$ century, especially those that concern students' education and training practitioners. Can lecturers in academia influence students to develop these soft skills actively, or are these interpersonal skills and intrapersonal traits innate character features? If soft skills and, specifically, intrapersonal traits can be actively influenced, the question raises how these could be developed in higher education, i.e. with which didactics. Therefore, it leads to the following research question: $(R Q)$ which interpersonal skills and intrapersonal traits can be actively developed in PSM in higher education with which didactics?

Since the PSM competences, literature mainly focuses on listing competences and has neglected to research the testing, experimenting and describing how future PSM education should be organised. This research fills this gap by presenting an educational experiment. The student-centred, learning-by-doing approach of Scholten and Dubois (2017) is adopted as part of this experiment and will be elaborated on in the theory section. In this research, the evidence is given that in a time frame of 8 weeks, with a study load of 140 hours, interpersonal skills and intrapersonal traits can be developed within the context of a real-life case.

\section{BACKGROUND}

\section{Theory on Soft Skills Development and Student-Centred Learning}

A keyword search in Google Scholar and Scopus was performed to conduct a systematic literature review, following Durach, Kembro, and Wieland (2017). The keyword search generated an initial set of 1,007 articles; a list of PSM job requirements was gradually extracted (displayed in Table 1). Articles regarding organisational (i.e., non-individual) competences or capabilities in the described fields and articles that focused on consumer skills of family household purchasing budget use were discarded, likewise minor citations. In the end, from 33 studies published between 1987 and 2020, skills requirements could be extracted (see: Appendix 1). 
Table 1 shows the PSM skills' occurrences stated at least once per article and showed little unanimity. Interestingly, a more significant proportion of the studies agreed upon the need for 'PSM knowledge' (82 per cent), as well as 'business knowledge' (76 per cent) and 'negotiation skills' (73 per cent), about one-third of the studies present items that the other studies did not propose, such as industry knowledge' (33 per cent), 'creativity' (33 per cent), 'or 'legal knowledge' (30 per cent).

Table 1 - PSM requirements mentioned in the scientific PSM job requirements literature (1987-2020)

\begin{tabular}{|c|c|c|c|c|c|}
\hline PSM knowledge & $80 \%$ & Curiosity / the will to learn & $37 \%$ & Entrepreneurial attitude & $10 \%$ \\
\hline Business knowledge & $73 \%$ & Industry knowledge & $33 \%$ & Result-driven & $10 \%$ \\
\hline Negotiation skills & $73 \%$ & Creativity & $37 \%$ & Consultancy Advisory skills & $10 \%$ \\
\hline Leadership skills & $70 \%$ & Legal knowledge & $30 \%$ & Power handling & $10 \%$ \\
\hline Relationship management & $63 \%$ & Quality management & $30 \%$ & Discipline & $10 \%$ \\
\hline Analytical thinking & $63 \%$ & Process management & $30 \%$ & Conscientiousness & $10 \%$ \\
\hline Holistic thinking & $63 \%$ & Blueprint reading & $33 \%$ & Will to compromise & $7 \%$ \\
\hline Computer literacy & $63 \%$ & Logistic knowledge & $27 \%$ & Self-confidence & $7 \%$ \\
\hline Team ability & $63 \%$ & Project management & $33 \%$ & Perseverance & $7 \%$ \\
\hline Communication skills & $57 \%$ & Written proficiency & $27 \%$ & $C A D$ & $3 \%$ \\
\hline Problem solving skills & $57 \%$ & Tactfulness & $27 \%$ & Own initiative & $3 \%$ \\
\hline Strategic thinking & $50 \%$ & Motivate skills & $27 \%$ & Empathy & $3 \%$ \\
\hline Decisiveness / decision making & $50 \%$ & Time management & $23 \%$ & Entreprise Resource Planning & $3 \%$ \\
\hline Organisational skills & $43 \%$ & Information management & $20 \%$ & Patience & $3 \%$ \\
\hline Risk management & $40 \%$ & Presentation skills & $20 \%$ & Common sense & $3 \%$ \\
\hline Persuasive skills & $43 \%$ & Assertiveness & $20 \%$ & Conference skills & $3 \%$ \\
\hline Conflict resolution & $43 \%$ & Flexibility & $20 \%$ & Loyalty & $3 \%$ \\
\hline Customer orientation & $37 \%$ & Mathematics/numeral skills & $13 \%$ & Pro-activity & $3 \%$ \\
\hline
\end{tabular}

The data were exposed to further analyses. Since Fawcett and Rutner (2014, p. 180) acknowledged that PSM practices in firms have "evolved dramatically over the past generation", the scientific sample was divided into ' $20^{\text {th }}$ century' $(1987-2001 ; n=16)$ and ' $21^{\text {st }}$ century' (2003-2020; $n=17$ ) sub-samples. Interestingly, no significant differences among the specific requirements were found with a $t$-test, indicating certain academic development stagnation. The advent of the Fourth Industrial Revolution might change the picture, however.

Table 1 displays PSM job requirements and the percentage of times they occurred for requirements mentioned at least once in a single scientific PSM article in the entire set of articles. The top rankings indicate a profile of a PSM professional who possesses accumulated knowledge (i.e., knowledge and experience) in PSM and business; who can negotiate, network and communicate; who can be both a team leader and member; who can think both analytically and holistically; and who can work with computer systems.

\section{The EU Directives on Higher Education's Role in Soft Skills Development}

According to the European ministers of education, institutions for higher education have to anticipate future competences since fostering innovation and creativity in society is a task for these institutions (Leuven/Louvain-la-Neuve Communiqué, 2009). Moreover, institutions in higher education endorsed the shift towards student-centred methods via 
the European Association of Institutions in Higher Education (EURASHE) and the European University Association (EUA). They co-developed with the European ministers of education the standards and guidelines for quality assurance in the European higher education area (ESG Report, 2015).

The ESG Report state: "Institutions should ensure that the programmes are delivered in a way that encourages students to take an active role in creating the learning process and that the assessment of students reflects this approach (...) Student-centred learning and teaching plays an important role in stimulating students' motivation, self-reflection and engagement in the learning process" ESG Report (2015, p. 12).

Hence, student-centred approaches are preferred, especially for the training of soft skills, attitudes or traits (e.g. Bals et al., 2019). Nevertheless, teacher-centred, frontal, and classical lectures can be considered the dominant higher education design for 'transferring' knowledge and theory (Hoidn, 2017). Multiple barriers cause the reason why universities are dominantly teacher-centred. Firstly, since dozens or hundreds of students can attend the same lecture, frontal teacher-centred methods are highly efficient, though not as effective as student-centred methods (Hannafin \& Land, 2000). However, it is doubtful whether a professional activity, such as education, can be efficient when effectiveness levels are low. According to Drucker (1977), a state of efficiency can be reached before effectiveness is established: "Effectiveness is the foundation of success - efficiency is a minimum condition for survival after success has been achieved. Efficiency is concerned with doing things right. Effectiveness is doing the right things" (Drucker, 1977, p. 33).

The learning effectiveness is hidden in learning, consisting of reconstructing bits of knowledge by students themselves. The learning process is not a 'transfer' of information from a lecturer directed towards the student; it is a genuine, personal process in the individual student's mind (Land \& Hannafin, 2000).

The shift from frontal, classical teaching towards student-centred didactics profoundly changes the working modus (Anthony \& Kadir, 2012). Traditional lecturers who change their didactics to student-centred approaches report "feelings of guilt" because the student-centred method seems to be initially "just guiding and supporting the students in the learning processes" and knowledge is no longer "transferred" in a classical, frontal mode (Anthony \& Kadir, 2012, p. 57). The guilt-feeling is caused by the wrongly expected loss of the lecturers' authority in the classroom when the lecture leaves behind the frontal, classical method (Anthony \& Kadir, 2012).

Moreover, despite their importance, the learning and teaching of soft skills are more complicated. Laker and Powell (2011, p. 113) distinguish "hard-skills or technical training (working with equipment and software) and soft-skills training (interpersonal or intrapersonal focus)" and found evidence that the soft skills learning process is associated with higher levels of resistance from both, the students/trainees and the management. Thus, soft skills training has not as direct applicability to the job as hard skills training. Therefore, soft skill learning results in a lower degree of achieved proficiency and selfefficacy. Moreover, the preciseness of identifying soft skills training objectives is lower (Laker \& Powell, 2011). This lower level of preciseness might also be the case for the identification of training methods. 
Moreover, the PSM competence literature has presented important competences (e.g. Bals et al., 2019; Giunipero \& Pearcy, 2000; Knight, Tu, \& Preston, 2014; Tassabehji \& Moorhouse, 2008), but has failed to present best practices on how these competences could be best taught. Whereas Feisel, Hartmann, and Giunipero (2011) found that these intrapersonal traits of experienced professionals and their strategic behaviour are difficult to influence, the research of Scholten and Dubois (2017) showed, though, the positive outcomes of an educational experiment in cohorts of students in a PSM course as is shown after the next section.

The PSM competence literature hardly provides outcomes of didactical experiments on applying the necessary soft skills, especially intrapersonal character traits in PSM courses in higher education. The question arises whether the prevailing conceptualisation of PSM is capable of comprising the $21^{\text {st }}$ century's complexity since the research community seems not to address the suitable didactical instruments for soft skills development to cope with the contemporary and future challenges in the field (e.g. C. R. Carter, Rogers, \& Choi, 2015; Darby, Fugate, \& Murray, 2019; Knight, Meehan, Tapinos, Menzies, \& Pfeiffer, 2020).

The literature might fail to address soft skills development in PSM courses in higher education because formalised soft skills intended learning outcomes are almost absent at European, US and UK universities. These are predominantly focused on just the transfer of knowledge and theory (Birou et al., 2016; Hoidn, 2017; Stinenbosch, 2017; Wong et al., 2014).

Interestingly, employers explicitly demand from institutions for higher education to formalise soft skills learning objectives (Mursion, 2021). Soft skills have an essential role in applying knowledge and cognitive skills in daily practice. Soft skills are crucial or even more important than cognitive and professional skills or 'hard skills' for a professional (Ahmed et al., 2012). That is because soft skills are necessary conditions to carry out hard skills, as explained in the introduction (Stek \& Schiele, 2021).

The presence of soft skills is an excellent forecaster to success in life, and an absence appears to be causing the ending of a labour relationship rather than a lack of cognitive skills (Ahmed et al., 2012; Heckman \& Kautz, 2012; Zunk \& Sadei, 2015). In line with that, Forrest and Swanton (2021, p. 1) have found evidence in a longitudinal study of secondary school pupils that "Self-reported problem solving, creativity, teamwork, and verbal communication were alternately associated with later high school performance, hourly wage, and employment status". Tuononen, Parpala, and Lindblom-Ylänne (2019, p. 581) found that "having diverse competences and an ability to recognise them at the time of graduation is important for later career success and may also be related to what kind of challenges graduates face in working life".

\section{Didactical approaches in higher education}

Due to changing labour market demands, higher education must anticipate adjusting the learning objectives early (Hoidn, 2017). Expectations are that in 2025 about 45 per cent of the European jobs will require high-level qualifications, and another 45 per cent will need medium-level capabilities. After graduation, students need the "ability to apply knowledge and skills flexibly in different contexts", and academia has to prepare "students 
with the subject-based know-how as well as with high-level transversal competences and skills such as joint problem solving, critical thinking, and self-regulated learning" (Hoidn, 2017, p. 2).

As abovementioned, formalised soft skills learning objectives are absent in higher PSM education. Several explanations are given in the literature. The training method or didactics of soft skills training differs from hard skills didactics. Soft skills development can be influenced by external stimuli but is nevertheless a personal effort, and it requires a student-centred approach. However, the dominant design at universities is teachercentred, frontal, and classical lecturing for hard skills (Hoidn, 2017). Teacher-centred techniques are more cost-efficient but less effective than student-centred methods (Hannafin \& Land, 2000). A shift from teacher-centred to student-centred didactics is a profound change of working modus that causes guilt when losing authority when not following frontal, classical didactics (Anthony \& Kadir, 2012).

The development of soft skills is more complicated than that of hard skills. It is associated with higher resistance levels from the learners because it does not have direct applicability as hard skills development (Laker \& Powell, 2011). Moreover, soft skill development leads to a lower degree of achieved proficiency and self-efficacy than hard skills development. Another issue is that the preciseness of distinguishing soft skills training objectives and methods is lower (Laker \& Powell, 2011).

Formalising soft skills learning objectives is further obstructed by the negative association lecturers in academia have. Chamorro-Premuzic, Arteche, Bremner, Greven, and Furnham (2010, p. 238) found that "IQ was negatively associated with soft skills ratings, such that individuals with higher cognitive ability were less likely to believe that soft skills were important for outstanding academic achievement or desirable job after graduating". Lecturers in academia believe that "lower ability students may use soft skills to compensate for their poorer analytic/reasoning skills, just as conscientious students are more likely to use soft skills to improve their academic performance".

Traditionally, lecturers at (European) universities use classical, frontal lecturing for 'transferring' knowledge and theory (Hoidn, 2017). The design of frontal teaching sets students in a passive listening role, which has the lowest effect on retaining knowledge (Masters, 2013), for which Poh, Swenson, and Picard (2010) even has provided empirical evidence.

Poh et al. (2010) measured a student's neurological activity over seven days with a device, a 'wearable sensor for unobtrusive, long-term assessment of electrodermal activity'. Poh et al. (2010) show that most neurological activity is found with the student during selfstudy, doing homework, doing laboratory work, exams, and sleeping (dreaming). Lesser brain activity is seen during watching television, relaxing and remarkably when following lectures in the classroom. Hence, for the student, having a classical, frontal lecture in most cases has the same neurological impact as watching television or remaining in a relaxing state of mind.

Poh et al. (2010) illustrate that learning consists of reconstructing knowledge by students themselves; the learning process is not a 'transfer' of information from a lecturer directed towards the student (Land \& Hannafin, 2000). De Houwer, Barnes-Holmes, and Moors 
(2013, p. 633) define learning as 'ontogenetic adaption', i.e. "as changes in the behavior of an organism that are the result of regularities in the environment of that organism".

Nevertheless, Hannafin and Land (2000) found that many lecturers in higher education are convinced that they could transmit the knowledge they possess to the individual students. Yet, there is broad agreement that the students have to reconstruct knowledge individually (Hannafin \& Land, 2000). In line with that, the European Commission in 2008 already noted that "traditional teaching approaches based on direct instruction or lecturing are no longer adequate" and that they have to be "replaced by more learnerfocused models that are based on the learner's active involvement in the process of reflection and interpretation" (Hoidn, 2017, p. 5). Active involvement in experiments is a way to activate students in their learning process to reach a comprehensive learning effect. Active involvement has better learning results than students who passively watch the same similar experiment demonstrated by a lecturer (Bonwell \& Eison, 1991).

\section{Towards a Student-Centred Approach}

Student-centred learning environments are a better alternative to the dominant design of classical, frontal instruction. The introduction refers to the ESG-standards from the year 2005 (ESG Report, 2015). The conclusion is that European higher education's educational methods still do not align with the ESG-standards (Hoidn, 2017; Stinenbosch \& Stek, 2017), although academia and higher education institutions were involved via the EURASHE and the EUA.

As mentioned, in PSM, not many experiments with knowledge transfer, interpersonal skills and intrapersonal traits development are described in the academic literature. A rare example is Scholten and Dubois' (2017) attempt to train students' competences. In subsequent cohorts at a Swedish and a Dutch university, case study projects have been performed in which supply chain management master students were assigned to project groups on writing a joint e-book on PSM.

Scholten and Dubois' (2017) describe the courses aimed to comprehend the state of the art PSM theoretically and practically. "The courses lie within the domain of project-based learning, one approach within the constructivist theory, where students are given an assignment to carry out one or more tasks that lead to the production of a final product" (Scholten \& Dubois, 2017, p. 1687).

The main conclusion is that "the teaching context influenced the learning process and the learning outcomes. Active involvement, self-directed learning, collaborative learning and learning from practice enabled by the set-up of the course are identified as key mechanisms for the learning outcomes in relation to skills and content" (Scholten \& Dubois, 2017, p. 1683).

Scholten and Dubois' (2017) approach develops students' and lecturers' cognitive, interpersonal and intrapersonal skills. Scholten and Dubois (2017, p. 1696) conclude that for a student-centred approach, educators need other lecturing skills: "due to students' active involvement in decisions regarding content and process, a lot of flexibility and creativity is required from individual lecturers," and they add: "Our results show that students who are actively involved in the learning process by taking responsibility, 
engaging in collaborative learning and by taking the chance to learn from practice are able to develop higher-order learning in relation to content as well as skills that are needed in today's job environment" (Scholten \& Dubois, 2017, p. 1696).

Compared to the traditional, classical way of lecturing methods, the method, as explained by Scholten and Dubois (2017), appears to be more in line with the Dublin descriptors (Dublin Descriptors, 2004). These descriptors are part of the Bologna Process and should be endorsed by all European higher education institutions. The Dublin descriptors state that learning objectives in general consist of both hard and soft skills: "(i) knowledge and understanding, (ii) applying knowledge and understanding, (iii) making judgements, (iv) communication skills and (v) learning skills" (Dublin Descriptors, 2004; Leoni, 2014, p. 4).

In higher education, classical, frontal teacher-centred lecturing is the dominant design, and the teaching is mainly focused on transferring knowledge and hard skills (Masters, 2013). However, the literature underlines the importance of soft skills development at universities and institutions for higher education. Therefore, based upon Scholten and Dubois (2017) and Laker and Powell (2011), the following is hypothesised:

Hypothesis: soft skills (interpersonal skills and intrapersonal traits) can be developed in PSM courses in higher education with learning-by-doing practices.

\section{METHODOLOGY}

\section{A Quasi-Experiment with Intrapersonal Skills in a PSM Course}

In this study, an experimental approach is pursued. It is following the call of Pettigrew (2001) for a form of 'management research after modernism' to "be prepared for a period of experimentation and learning" (Pettigrew, 2001, p. 69). Darby et al. (2019, p. 1) calls for an "expanding the methodological toolbox" of PSM and alert not to use just a sheer observative, sociological positivist approach. This plea of Darby et al. (2019) can be associated with Hacking (1984, p. 154), who stated that: "no field in the philosophy of science is more systematically neglected than experiment."

The design of measurement in education is normally a pre-experimental design that is "the exposure of a group to an experimental variable or event, the effects of which are to be measured," (X) followed by "some process of observation or measurement" (O) (Campbell \& Stanley, 1966, p. 6). Hence, the standard set-up in education is X-O, primarily a series of lectures followed by a test referred to by Campbell and Stanley $(1966$, p. 6) as "the one-shot case study".

For this research, an $\mathrm{O}_{1}-\mathrm{X}-\mathrm{O}_{2}$ design has been set up, or "the one-group pre-test - posttest design", which is preferred over an X-O design and "to be worth doing where nothing better can be done" (Campbell \& Stanley, 1966, p. 6), which is the case, although a design with a control group would have been a better alternative. In that case, the focal group would perform the surveys and follow the lectures $\left(\mathrm{O}_{1}-\mathrm{X}-\mathrm{O}_{2}\right)$, and the control group would only perform the surveys $\left(\mathrm{O}_{1}-\mathrm{O}_{2}\right)$. Since there was no access to a control group, "pre-test - post-test control group design" could not be completed (Campbell \& Stanley, 1966, p. 6). The $\mathrm{O}_{1}-\mathrm{X}-\mathrm{O}_{2}$ design in this study consisted of two identical surveys $\mathrm{O}_{1}$ and $\mathrm{O}_{2}$, and the experiment X: a 5 ECTS course with (online) lectures, workshops, case study, academic writing and self-study in between both surveys. 
The used method to assess the difference between $\mathrm{O}_{1}$ and $\mathrm{O}_{2}$ is the Paired-Samples or Dependent $t$-test, for which the Confidence Interval Percentage is set at 95 per cent. The missing values are set to be "excluded by analysis". The students filled out the first survey before the end of the first week of the ten-week course. The same students filled out the second survey before the end of the last week of the course. The 'mean' results are derived from subtracting the different items' outcomes in the second survey from the first survey. Both surveys were measured on a 5-point-Likert scale from "fully disagree" (1) to "fully agree" (5). Moreover, Cohen's $d$ effect sizes are calculated. The effect size are considered to be 'small' $(.2<d<.5)$; 'medium' $(.5<d<.8)$; or 'large' $(.8<d<1.2)$ by Cohen (1988, pp. 25-26).

Campbell and Stanley (1966) note that an $\mathrm{O}_{1}-\mathrm{X}-\mathrm{O}_{2}$ design comes with internal validity problems. Primarily, 'history' forms a threat to validity. "Between $\mathrm{O}_{1}$ and $\mathrm{O}_{2}$, many other change-producing events may have occurred in addition to the experimenter's X" (Campbell \& Stanley, 1966, p. 6). In this study, a one-group pre-test-post-test design experiment is performed in a cohort of students in an elective, introductory PSM course for the master curriculum Industrial Engineering Management and master students in the Business Administration track are enrolled. Parallel to the course, the participating students followed in the same period, on average, two other courses that might have affected the second survey outcomes $\left(\mathrm{O}_{2}\right)$.

Consequently, the quasi-experiment was not performed with a parallel group of students in another traditional course that has not incorporated interpersonal skills and intrapersonal traits development in the learning objectives. Nevertheless, the results show an increase in some interpersonal and intrapersonal skills. It is uncertain whether this increase was gained due to its specific learning objectives and training methods. Further, the increase between survey $\mathrm{O}_{1}$ and $\mathrm{O}_{2}$ could be due to other parallel courses in the curriculum or other private life circumstances.

Finally, some students stated that becoming conscious of the competence level caused differences between the two surveys, known as the Dunning-Kruger effect (Kruger \& Dunning, 1999), i.e. unskilled persons tend "to hold overly favourable views of their abilities in many social and intellectual domains" (Kruger \& Dunning, 1999, p. 1121). However, skilled persons have the tendency "to underestimate their performance relative to their peers" (Kruger \& Dunning, 1999, p. 1126).

There is a possibility that this effect occurred that student overestimated their perceived competence levels in the first survey and understated those in the second. The study is an experiment that measured in a timeframe of eight weeks twice the perceived competence levels. Between both surveys, the student got trained and skilled and might have developed from unaware to aware of their incompetence. There is a risk that the students filled out the first survey overstating competence levels and understating those in the second.

\section{Course design in three lines: knowledge, skills and attitudes/traits}

The course attracted 95 students (30 females and 65 males; 82 Dutch students, seven citizens from other EU-countries and four from non-EU countries) in three subsequent cohorts in 2018-2019 (30 students: 8 females and 22 males; 24 IEM and 6 BA students; 
average age 23.7, $\delta=1.75$ ); in 2019-2020 (26 students: 12 females and 14 males; 19 IEM and 7 BA students; average age 23.0, $\delta=1.06$ ); and in 2020-2021 (39 students: 10 females and 29 males; 28 IEM and 11 BA students; average age 24.3, $\delta=2.52$ ). About 75 per cent of the students were enrolled at the master track IEM and 25 per cent at BA studies. Students from both tracks were randomly assigned to working groups. The course consisted of about 16 lectures and workshops of 90 minutes and was divided into a knowledge line, a skills line, and an attitude or intrapersonal traits line, which formed the whole construct of the experimental approach of the course $(X)$.

The researched sample consists of IEM and BA master students of an elective, introductory course, Purchasing Management, at a Dutch polytechnical university. The master course has been designed in such a way that it offered education in (1) knowledge and theory, (2) professional and interpersonal skills, and (3) intrapersonal traits. The didactical construct provided a mix of frontal, classical instructions, a Massive Open Online Course (MOOC), practical workshops, storytelling and learning-by-doing in two larger projects with tutoring meetings. The course philosophy is that competence consists of knowledge and theory, professional and personal skills and intrapersonal traits or attitudes (e.g. Campion et al., 2011; Delamare-Le Deist \& Winterton, 2005). The knowledge and soft skills training served the case-solving (professional and personal skills) part, and the case gave meaning to the course's content.

The course syllabus stated: "Aims - To acquire 'success skills' from practice [knowledge (hard skills) as well as interpersonal as intrapersonal skills] to analyse the performance of the purchasing function in an organisation and make well-founded, inventive decisions on complex strategic purchasing issues" (...). "The didactic of this course is (...) entirely student-centred: PSM professionals are invited to perform active workshops on the content and the personal development, and the further lectures are built upon student participation. Each student group works out one of a dozen subjects and are subsequently digesting the textbook, journal articles and reports into a working paper and presentation. The students are encouraged to work in teams, communicate in a cross-cultural setting, consider calculated risk, think out-of-the-box, and find creative and inventive solutions to complex solutions problems to access the PSM content and theories. The aim is to (further) develop individual traits that are indispensable for a future career as a professional".

De Houwer et al. (2013, p. 633) defined learning as "ontogenetic adaption", i.e. "as changes in the behavior of an organism that are the result of regularities in the environment of that organism". Hence, effective learning leads to a sustained, long-term impact on the learner. Therefore, in the course, 'Constructive alignment' is applied, an educational approach introduced by Biggs (1996, p. 347) that combines two ways of thinking: "the first derives from constructivist learning theory and the second from the instructional design literature". Central in constructivism is creating the meaning of the learner's activities, impacting the teaching and assessment methods. The "Instruction design" underlines the alignment between a course's learning objectives and the student's performance assessment methods.

Biggs (1996, p. 347) combines both ways to "Constructive alignment". Constructivism is applied as the instructional design framework to create curriculum objectives "in terms of performances that represent a suitably high cognitive level, in deciding teaching/learning activities judged to elicit those performances and to assess and 
summatively report student performance" (Biggs, 1996, p. 347). Whereas the definition of competence by Campion et al. (2011) or Delamare-Le Deist and Winterton (2005) reveals a triangle of (1) knowledge and theory, (2) professional and interpersonal skills, and (3) intrapersonal traits, Biggs' (1996) Constructive alignment alerts educators to align (I) intended learning outcomes, (II) didactical approaches and (III) assessment methods. Therefore, for each of the three lines in the course, Constructive alignment is applied. The learning of knowledge and theory, professional and interpersonal skills, and intrapersonal traits differ in intended learning outcomes and hence also in didactics and assessments methods, as is shown below.

The knowledge line's practical substance consisted of an assignment to the students to co-author a book entitled 'State of the Art of Purchasing and Supply Management', inspired by Scholten and Dubois (2017). Teams were formed of about three students and were assigned to write a scientific paper, i.e. book chapter on a PSM topic. At Dutch universities, lecturers usually leave the initiative with the students to team up in groups. In most cases, this appears to lead to mono-cultural, uni-gender teams of acquainted students, which would not necessarily represent the daily practice in these graduates' future professional lives; usually, professionals cannot pick their fellow team members.

For each book chapter assignment, a topic and some guidance were given, such as two or three crucial articles and how to start academic writing. The book chapter project urged them to use the most recent literature and cite a minimum of 15 peer-reviewed articles. The use of the annotation program EndNote was set obligatory. Each student group was invited at least twice to meet the lecturer for 30 minutes to structure and improve the paper writing process. After the deadline and the lecturer's final editing, the book with ten chapters was made available in pdf format via intranet and was handed out in hard copy during the open-book exam. The student groups presented their chapter in a 15-minutes PowerPoint presentation during the final lectures.

However, the lecturer again teamed up the students for the skills line in other groups than for the book chapter writing assignment. The reason for that is twofold. Firstly, it is unlikely that professionals can form their teams or be consigned to two identical groups in professional life. Secondly, teaming up in different teams avoided exchanging tasks between students, leading to freeriding in one of the projects.

Real-life case studies were co-developed with the purchasing department of the university. The cases regarded the public tender procedures of tenders that would be carried out a few months later by the purchasing department. In the different lectures in the subsequent academic years, workshops were organised with guest speakers, such as chief purchasing officers (CPO) and purchasing experts.

In the case of kick-offs, the university purchasers, contract-owners and contract managers had a role. The case studies have been designed to be easily explained: e.g. 'the university needs new faculty housing' or 'the contract of the hot beverages vending machine is ending' and 'a tender procedure is upcoming'. Nevertheless, these 'simple' problems were hard to solve due to all the facets, like stakeholders' interest, sustainability issues, et cetera.

The case studies were subtitled 'talking with real people'. Therefore the written info in the case study assignments was limited. Instead, the students were invited to raise oral 
questions to obtain more information from the purchasers, contract-owners and contract managers, who are the real people who will work on the same case in real life in the following months. These practitioners, who work for the university, cooperate for different reasons. One reason is the willingness to contribute to the university's educational process and stay connected to the employers' core business. Another critical reason is exchanging ideas with the students, the guest speakers and the lecturers to get insights from a new angle and obtain a synergy advantage in the upcoming tender procedures.

For both the knowledge and the case line, in 2018 and 2019, classical and in 2020, due to the Covid-lockdown, online, frontal instruction lectures were provided on topics like public procurement procedures and the selection and awarding; purchasing management; supplier selection; and innovation sourcing. In addition, in the attitudes or intrapersonal traits line, several workshops were provided, such as a CPO's workshop on ethical behaviour and sound leadership, an interim management and consultancy agency workshop on consultancy skills, a creativity activation workshop and other necessary skills in a purchasing consultancy job; a negotiation lecture and workshop. Hence, the students are engaged with stories, experiences and workshops of several practitioners in the attitudes/traits line that served their performance in the case study. The cognitive lectures and paper writing in the knowledge line also partly served the solving of the case studies.

The third line in the course regarded the development of attitudes or intrapersonal traits. For this line, the one-group pre-test - post-test design experiment is performed in an $\mathrm{O}_{1^{-}}$ $\mathrm{X}-\mathrm{O}_{2}$ design, whereas $\mathrm{O}_{1}$ (observation 1 ) represents the first survey that was held in the first week of the course; $X$ (exposure) represents the exposure to soft skills training; and $\mathrm{O}_{2}$ (observation 2) represents the second survey that is identical to the first and was held in the last week of the course.

The survey consisted of 36 interpersonal skills and intrapersonal traits with a five-point Likert scale ("fully disagree" [1] to "fully agree" [5]). The 36 interpersonal and intrapersonal skills (see: Appendix 2) were derived from Stek and Schiele (2021), who performed an extensive PSM competence survey for the Erasmus+ PSM education project PERFECT, for which they selected 88 hard and soft skills items. Stek and Schiele (2021) derived these items from PSM competence literature (e.g. Giunipero \& Pearcy, 2000; Tassabehji \& Moorhouse, 2008) and depended for most of the soft skills items on $\mathrm{KODE}^{\circledR} \mathrm{X}$, which is a tool for the exploration of strategic corporate competency requirement profiles of requirement-or task-specific skills-set profiles and skills of potential employees and managers used. $\mathrm{KODE}^{\circledR} \mathrm{X}$ was developed for an assignment to change the professional roles of 140 engineers and architects towards a job as project manager (Erpenbeck \& Scharnhorst, 2005; Heyse, Erpenbeck, \& Max, 2004).

The first survey in the experiment in the three cohorts was taken before the second lecture, and the second survey was taken after the final lesson. Thus, the first survey's results were kept unrevealed for the individual students until after filling out the second survey. Therefore, when filling out the second survey, the individual students were unaware of their initial scores in the first survey about eight to ten weeks earlier. After the course, students compared their scores and handed in a reflection on the course, including a personal development plan. For the analysis, Paired Samples or Dependent $t$ - 
tests were performed. The four main assumptions of Paired Samples $t$-test have been met. The dependent variable is continuous, are normally distributed and does not contain any outliers. Moreover, the observations were independent of one another (Field, 2009). For the surveys, ethical approval was received from the university's Ethics Committee, and all students approved the use of anonymised data for scientific use.

\section{RESULTS}

\section{An Increase of Levels of Interpersonal Skills and Intrapersonal Traits}

The results of both surveys or observations $\mathrm{O}_{1}$ and $\mathrm{O}_{2}$ as per Campbell and Stanley (1966) were subject to Dependent $t$-tests. In total, 26 items showed a significant difference, and ten did not, as shown in Table 2. Herewith an answer is given to the research question on which soft skills can be developed. Moreover, there is enough evidence not to reject the hypothesis; indeed, the evidence is found for a substantial number of soft skills that these can be developed in a relatively short time frame of a ten-week course of 5 ECTS with the described didactics: a mix of frontal, classical instructions, a MOOC, practical workshops, storytelling and learning-by-doing in two larger projects with tutoring meetings.

The course was successful in increasing 'strategic thinking', 'negotiation skills' and 'salesperson skills' with significant $p$-values $(p<0.01)$ and 'medium' Cohen's $d$ effect sizes $(.5<d<.8)$ (Cohen, 1988, pp. 25-26; Sawilowsky, 2009). 'Strategic thinking' has the strongest effect size, meaning that the progress that the student sample made for this survey item is significant $(p<.000)$ and with a 'medium' effect size (Cohen, 1988, pp. 2526; Sawilowsky, 2009). 'Strategic thinking' was part of the case study's learning objectives; a lecture and workshop in strategic management were part of the case. The first assignment in the case consisted of forming a vision on higher education development in the following decades to define the building's purpose on the university campus.

'Negotiation skills' improved significantly, and the effect size is 'medium' ( $p=.000 ; d=.636$ ) (Cohen, 1988, pp. 25-26; Sawilowsky, 2009). 'Negotiation skills' are explicitly practised during the negotiation workshop. 'Salesperson Skills' has a significant outcome with a medium effect size ( $p=.000 ; d=.538)$.

Furthermore, the course improved networking, teamwork, leadership, problem-solving, cross-functional management, communication skills, and empathic capacity to a lower extent, showing lower significances $(.01<p<.05)$ and smaller effect sizes. Cohen's $d$ effect sizes in these cases are 'small' $(.2<d<.5)$ (Cohen, 1988; Sawilowsky, 2009). In the onegroup pre-test - post-test, the students filled out identical surveys before and after the course and self-reported their skills levels in 36 skills as displayed in Table 1.

The course caused a significant difference in 'strategic thinking,' a relatively lower-ranked item in the students' sample means. On a 5-point Likert scale, the students' mean in $\mathrm{O}_{1}$ was 2.70, and in $\mathrm{O}_{2}$, it increased to 3.21. The impact of the course is considerable but should not be exaggerated. The course has played a role in developing students' cohorts from a lower level towards a more average strategic thinking level and is undoubtedly not excellent. For example, the listing of 36 competence items 'strategic thinking' was 
ranked 29 in $\mathrm{O}_{1}$ and $\mathrm{O}_{2}$. It increased to rank 15 (see: Appendix 2). 'Salesperson skills' and 'negotiation' remained at respectively rank 35 and 36.

Table 2 - Effect sizes of significant differences $O_{1}$ and $O_{2}$ interpersonal and intrapersonal skills levels in a Paired-Samples or Dependent t-test

\begin{tabular}{|c|c|c|c|c|c|c|c|c|}
\hline & & \multicolumn{4}{|c|}{$\begin{array}{c}\text { Paired } \\
\text { Differences }\end{array}$} & \multirow[b]{2}{*}{ 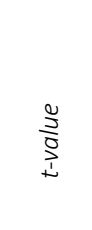 } & \multirow{2}{*}{ 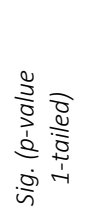 } & \multirow[b]{2}{*}{$\begin{array}{l}0 \\
-\frac{n}{\delta} \\
\frac{\tilde{J}}{0} \\
u\end{array}$} \\
\hline & & $\begin{array}{l}\overrightarrow{7} \\
\stackrel{\vec{े}}{5} \\
\stackrel{5}{n}\end{array}$ & 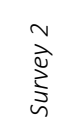 & $\frac{\delta}{\delta}$ & ڤ & & & \\
\hline 1 & Strategic Thinking & 2,70 & 3,21 & .518 & .713 & 5.433 & .000 & .726 \\
\hline & Negotiation skills & 2,21 & 2,71 & .500 & .786 & 4.759 & .000 & .636 \\
\hline 3 & Salesperson skills & 2,36 & 2,80 & .446 & .829 & 4.028 & .000 & .538 \\
\hline 4 & Networking / Building Relations & 2,49 & 2,86 & .351 & .772 & 4.409 & .000 & .455 \\
\hline 5 & Communication skills & 3,06 & 3,34 & .362 & .914 & 3.837 & .000 & .396 \\
\hline 6 & Decision-making & 2,83 & 3,16 & .309 & .804 & 3.722 & .000 & .384 \\
\hline 7 & Cross-functional management & 2,86 & 3,23 & .391 & .828 & 3.772 & .000 & .472 \\
\hline 8 & Ability to Solve Problems & 3,13 & 3,38 & .277 & .768 & 3.493 & .000 & .360 \\
\hline 9 & Comprehension of Complexity & 2,95 & 3,19 & .245 & .683 & 3.474 & .000 & .358 \\
\hline 10 & Capacity to be empathetic & 3,34 & 3,66 & .339 & .721 & 3.524 & .000 & .470 \\
\hline 11 & Leadership/community management & 2,51 & 2,89 & .359 & .824 & 3.491 & .000 & .436 \\
\hline 12 & Flexibility and agility & 2,79 & 3,07 & .277 & .835 & 3.212 & .001 & .331 \\
\hline 13 & Creativity & 2,60 & 2,83 & .213 & .670 & 3.079 & .001 & .318 \\
\hline 14 & Inventiveness & 2,58 & 2,86 & .277 & .873 & 3.073 & .001 & .318 \\
\hline 15 & Persistence & 2,70 & 3,04 & .339 & .837 & 3.033 & .002 & .405 \\
\hline 16 & Proactivity & 2,87 & 3,10 & .213 & .731 & 2.821 & .003 & .279 \\
\hline 17 & Teamwork & 3,17 & 3,47 & .313 & .889 & 2.813 & .003 & .351 \\
\hline 18 & Cross-cultural awareness & 2,86 & 3,06 & .245 & .876 & 2.708 & .004 & .279 \\
\hline 19 & Willingness to take risks & 2,83 & 3,14 & .191 & .766 & 2.424 & .009 & .250 \\
\hline 20 & Customer-oriented & 3,14 & 3,27 & .191 & .846 & 2.195 & .015 & .226 \\
\hline 21 & Stress management & 2,98 & 3,16 & .297 & 1.122 & 2.116 & .019 & .265 \\
\hline 22 & Willingness to Learn & 2,87 & 3,02 & .160 & .780 & 1.983 & .025 & .204 \\
\hline 23 & Capacity to Advice & 2,87 & 3,03 & .181 & .904 & 1.941 & .028 & .200 \\
\hline 24 & Holistic Thinking & 3,11 & 3,28 & .149 & .747 & 1.933 & .028 & .199 \\
\hline 25 & Poise & 2,66 & 2,80 & .149 & .747 & 1.933 & .028 & .199 \\
\hline 26 & Task management & 3,38 & 3,47 & .219 & .917 & 1.909 & .030 & .239 \\
\hline 27 & Power of Persuasion & 2,95 & 3,12 & .143 & 699 & 1.530 & .066 & .204 \\
\hline 28 & Result-orientated action-taking & 2,94 & 3,05 & .128 & .688 & 1.422 & .079 & .147 \\
\hline 29 & Self-assurance & 2,73 & 2,94 & .106 & .809 & 1.274 & .103 & .131 \\
\hline 30 & Inter-generation skills & 2,96 & 3,09 & .156 & .996 & 1.256 & .107 & .156 \\
\hline & Honesty & 3,67 & 3,74 & .096 & .804 & 1.154 & .126 & .119 \\
\hline 32 & Conscientiousness & 3,47 & 3,50 & .125 & .833 & 1.124 & .133 & .150 \\
\hline 33 & Social Manners & 3,32 & 3,32 & .096 & .881 & 1.054 & .147 & .108 \\
\hline 34 & Ability to Resolve Conflicts & 3,21 & 3,27 & .096 & .928 & 1.000 & .160 & .103 \\
\hline & Critical thinking & 3,15 & 3,25 & .107 & .867 & 0.925 & .180 & .124 \\
\hline & Loyalty & 3,69 & 3,77 & .053 & .884 & 0.583 & .281 & .060 \\
\hline
\end{tabular}

See Appendix 2 for the item's definitions. The sample consists of Business Administration and Industrial Engineering and Management Master students ( $n=94$ ) in the cohorts 2018-2019 (n=30), 2019-2020 (n=26), and 2020-2021 ( $n=38$ ) of the introductory course Purchasing Management at the University of Twente. Used method: Paired t-test; Confidence Interval Percentage: 95 per cent; Missing Values: Exclude cases analysis by analysis (Cohen, 1988, pp. 25-26; Sawilowsky, 2009). 


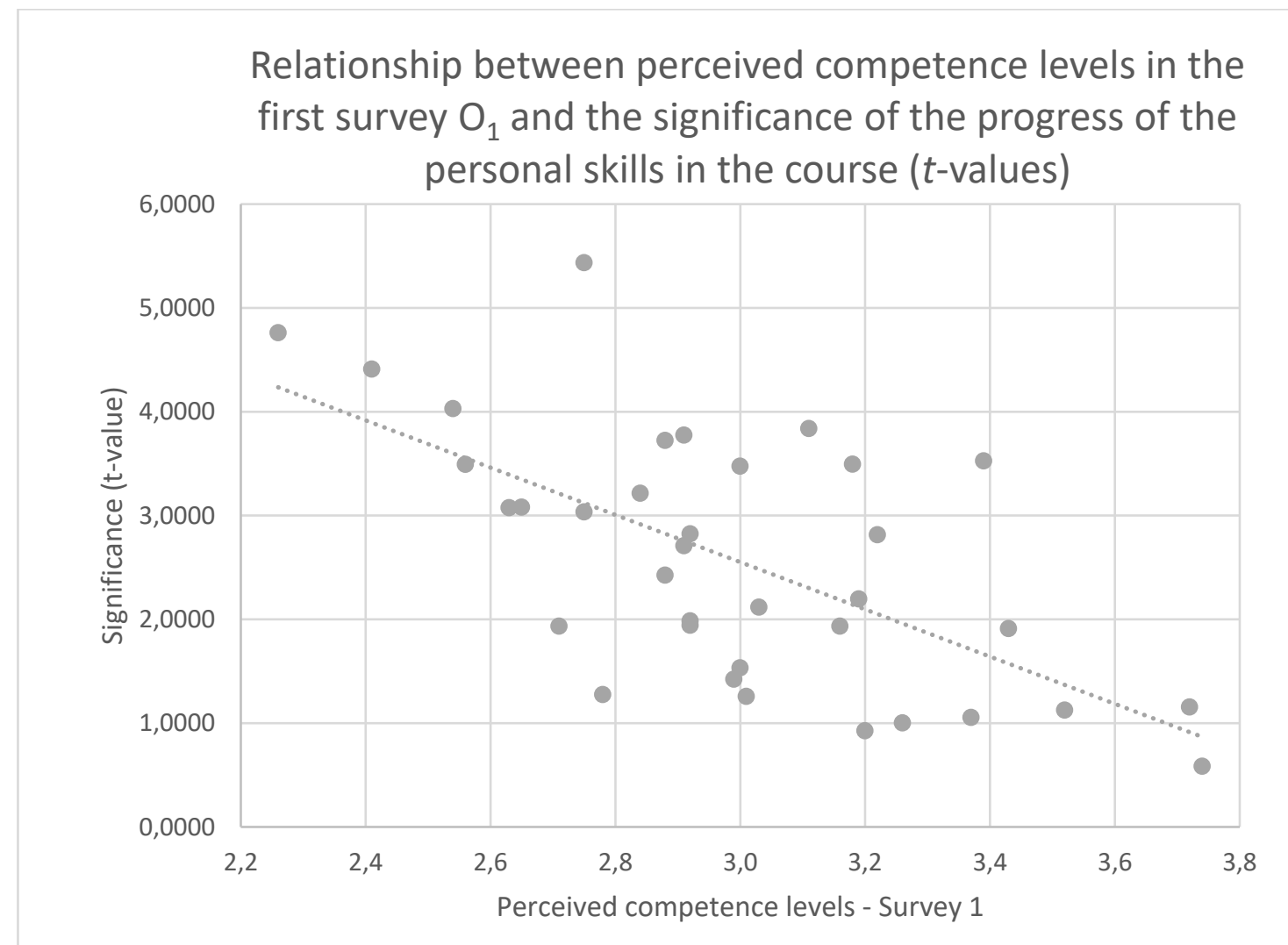

Figure 1-Graph displaying the relationship between perceived competence levels in $O_{1}$ and the significance of the progress of the personal skills in the course (t-values)

Note: This figure displays the relationship between the perceived competence levels in survey $1\left(O_{1}\right)$ and the significance of the progress in perceived competence levels from survey $1\left(O_{1}\right)$ to survey $2\left(O_{2}\right)\left(t\right.$-values) $\left(R^{2}\right.$ Linear $\left.=.402\right)$. In other words, skills items with lower scores in the first survey are more likely to improve during the course than skills items with higher scores.

Table 3 - Regression output belonging to Figure 1

\begin{tabular}{|c|c|c|c|c|c|}
\hline & & oefficients ${ }^{2}$ & & & \\
\hline & Uns & lardised & Standardised & & \\
\hline & & cients & Coefficients & & \\
\hline & B & Std. Error & Beta & $t$ & Sig. \\
\hline (Constant) & 9.265 & 1.410 & & 6.573 & .000 \\
\hline Perceived competence level (survey 1 ) & -2.276 & .476 & -.634 & -4.781 & .000 \\
\hline
\end{tabular}

a. Dependent Variable: Significance of progress (t-values)

Therefore, the initially lower-ranked competences are more likely to be subject to improvement. It is not surprising that the survey items with a higher self-rated competence level cannot be improved as those with lower self-ratings since the first set of items are developed, and the latter are underdeveloped. In other words, the proverbial low-hanging fruit is found in lower self-rated competences. Figure 1 the two rankings of the 36 competence items displayed in a scatter plot: the ranking in $t$-values from low to high and the perceived competence level from low to high on the 5-point Likert scale. 
The trendline reveals a negative relationship between both. Hence, the lower the initially perceived competence level, the higher the chance of a significant improvement. Table 3 shows evidence that the slope of the regression is significant $(p=.000)$. The $R^{2}$ is .402 .

\section{SOLUTIONS AND RECOMMENDATIONS}

\section{Contextual fundament for attitudes / intrapersonal traits development}

The research question is: which interpersonal skills and intrapersonal traits can be actively developed in PSM in higher education with which didactics? The skills items are displayed in Table 1; however, the second part is not answered explicitly. The didactical approaches of the experiment are multiple. The knowledge and theory line was dominated by (1) frontal, classical instruction, (2) the use of a MOOC, (3) the literature review writing assignment. This assignment led to the writing of chapters of a joint book used for the exam. The lecturer facilitated the writing of literature reviews with at least two 30minutes tutoring meetings with the groups on the form and content of the chapter. The exam and the literature review were graded. For the literature review, a scoring rubric is developed.

The professional and interpersonal skills lines didactics were focused on learning-bydoing in practical workshops given by experts on negotiation and advisory or consultancy skills. Moreover, the students were assigned randomly to groups and could not form their team. It led to diverse, non-mono-cultural groups that would not usually appear in master courses, i.e. teams consisting of members with the same nationality and mother tongue and teams formed by students from the same gender. Moreover, the students had to present the results of the case study and literature review for their cohorts. The case study reports and presentations were graded following a rubric.

The intrapersonal traits or attitudes didactics were offered via storytelling and learningby-doing. A CPO shared experiences in cross-cultural settings, with ethical issues and personal leadership. In a creativity lecture and workshop, the students were instructed how creative team processes occur and were encouraged to practice this in the case study groups. The assessment of this line was handing in a personal reflection and development plan based upon the differences in both surveys. The plans formed a necessary condition to receive the final grade and were not graded; handing in a "serious" plan was enough, and all students in all cohorts handed in "serious" reflections.

Hence, as shown in Table 2 and Figure 1, the students could acquire lesser developed soft skills. The three lines in the experiment formed an intertwined construct of learning knowledge and theory, professional and interpersonal skills, and intrapersonal traits or attitudes with multiple didactics and assessment methods.

Remarkably, two forms of thinking, 'critical thinking' and 'strategic thinking', represent the second lowest and the highest significance and effect size. Moreover, 'critical thinking' is perceived as a Top-10 ranked competence with the surveyed students, whereas 'strategic thinking' is ranked amongst the lowest ten. The students stated that they developed critical thinking in the four to five years of academic training (and over ten years of elementary and secondary school education). Strategic thinking, however, appeared to be underdeveloped. 
Therefore, students could be more familiar with the term 'critical thinking' since they might have been primed with the notion that 'critical thinking' is a desirable objective for a student in general. In literature, there is a discourse on 'thinking'-learning objectives, like 'critical thinking', 'academic thinking', et cetera. The discourse is led by Willingham (2008), who questions whether critical or other kinds of specific thinking are skills on its own: "If you remind a student to 'look at an issue from multiple perspectives' often enough, he will learn that he ought to do so, but if he doesn't know much about an issue, he can't think about it from multiple perspectives" (Willingham, 2008, p. 21). Willingham (2008) pleas for critical or other specific thinking in a given context, which is in line with Delamare-Le Deist and Winterton's (2005) definition of competency as a construct of three elements, knowledge, skills, abilities and other characteristics.

'Strategic thinking' is a skill that employers appreciate (Bals et al., 2019). The literature shows that attitudes and intrapersonal traits as 'strategic thinking' are hardly taught in academia (Birou et al., 2016; Wong et al., 2014). Thus, the course was directed on the strategic purchasing management theory and urged the students to think about strategic PSM-related problems. The case study provided a context to the thinking process.

Competence items that were part of the survey but were not formalised in the learning objectives for the introduction course to Purchasing Management, such as 'salesperson skills' and the 'willingness to take risks', showed a remarkable improvement. However, the modern purchaser needs these entrepreneurial skills, which have already been confirmed by Giunipero and Pearcy (2000). Other significant unintended improvements are 'persistence', 'proactivity', 'teamwork' and 'cross-cultural awareness'. The evidence is provided with the sample consisting of business master students who are used to working in student groups, 'teamwork' skills can be improved significantly when these students are assigned to groups instead of form groups, i.e., continuing in old structures.

As stated in the introduction, the transfer of knowledge and theory has a significant role in higher education. Indeed, the importance of knowledge and theory is undeniable. However, soft skills (i.e. interpersonal skills and intrapersonal traits) are necessary to carry out professional tasks (Stek \& Schiele, 2021). Moreover, employers highly value soft skills, and the lack of soft skills is more likely to be the reason for ending a labour relationship than a lack of knowledge (Ahmed et al., 2012).

For the operationalisation of strategic management knowledge and theory, strategic thinking or strategic handling is needed. In strategic management courses, students are taught strategic management knowledge and theory (which was also done in the course). However, in most of these courses, the students are not taken to the next level of carrying out strategic management and lack competences in strategic thinking. Delamare-Le Deist and Winterton (2005) showed evidence that knowledge, skills, and attitudes form a construct and Willingham (2008) expresses that attitudes and traits should be developed within a context (of knowledge and theory).

Giunipero (2000) distinguishes between hard skills (PSM knowledge and skills) and soft skills (intrapersonal traits and intrapersonal traits in PSM). A "world-class purchaser" is "continuously improving his/her skills; (...) is focused on professional development and education; (...) is willing to change and adapt; is a problem solver seeking the best solution; is flexible; (...) is ethical; (...)" and "adapts well to change" (Giunipero, 2000, p. 8), within the PSM context, as suggested by Willingham (2008). 
RQ1 is focused on which soft skills 'could' be developed. Like is hypothesised, the evidence is shown that soft skills can be trained, which is confirmed by Laker and Powell (2011), although they mention that soft skills training comes with higher levels of resistance from participants and their managers. Students characterised the course as "different" from other courses and confirmed in their reflections that they could improve their soft skills in the course.

A male IEM-student in the cohort 2020-2021 noted: "The case we got to work on was very interesting and had a lot of room for creativity. Because it was a group assignment, you could also learn a lot from the creativity of your project members. This has had a positive effect on my own creativity skill. The assignment that came with the case had almost no guidelines. This also meant that you had to estimate for yourself what was asked". A female BA-student in the 2020-2021 cohort: "I thought the creativity lecture and workshop were interesting! It showed and taught me more ways of how to think of creative ideas and concepts. I think these might be very interesting for my future worklife".

A female IEM-student in the 2020-2021 cohort elaborate on what is referred to above as the Dunning-Kruger effect: "For the skill creativity, i.e. being creative in professional life / having creative ideas, the difference was -1 (i.e. the score of survey $\mathrm{O}_{1}$ minus that $\mathrm{of}_{2}$ ). The reason behind this is that after attending the lecturer's creativity lecture, I had a different view on creativity. During the lecture, the lecturer mentioned that "creativity leads to innovativeness when it is novel and useful". During my working experience, I had many business ideas that were not that useful. (...) I had a very poor view of what this skill actually meant, but after the course, I could reflect on my working experience and noticed that I actually do manage this skill very well".

\section{CONCLUSION}

Hence, the question of whether soft skills 'could' be taught is answered, i.e. that the selfperceived competence levels of most soft skills have improved significantly. Nevertheless, Laker and Powell's (2011) findings trigger whether, in academia, soft skills should be taught. As shown by Ahmed et al. (2012) and many scholars in the PSM competence field, employers would agree (e.g. Bals et al., 2019; Feisel et al., 2011; Giunipero \& Pearcy, 2000). The European ministers of Education also would agree, according to the statement that: "Higher education should be based at all levels on the state of the art research and development thus fostering innovation and creativity in society" (Leuven/Louvain-laNeuve Communiqué, 2009, p. 4).

Interestingly, many parties would agree that soft skills, more precisely intrapersonal traits learning objectives, should be applied in academic courses, most notably by employers, politicians, and PSM scholars. Nevertheless, academia failed to offer a balanced volume of knowledge and theory, professional and interpersonal skills and intrapersonal traits. Hence, soft skills 'could' and 'should' be taught in higher education, but they are absent in intended learning outcomes. It raises the question of whether soft skills 'would' be taught in academia. Moreover, soft skills education is less attractive for all stakeholders. Students, trainees, and management prefer hard skills over soft skills education (Laker \& Powell, 2011), and lecturers feel guilty when shifting to student-centred methods (Anthony \& Kadir, 2012). 
The student evaluations made it clear that the course was mostly positively evaluated and was experienced as 'different from other courses'. Remarkably, the students in the cohort 2020-2021 that, due to the Covid-measurements, followed most of the lectures online, seem to have appreciated the course better than the preceding cohorts. Probably, the reason why the students enjoyed the course in times of Covid lockdowns and distant learning was because of the student-centred approach. The course demanded many (online) interactions. The students worked in two separate teams on the book chapter and the case, and per group, multiple mentor meetings were planned with the lecturer.

The students revealed that they would usually start studying the lecture notes and PowerPoint presentations a week or two before the exams. In this course, the students studied their lecture notes earlier because the knowledge formed the case context or the book chapter. The evidence shows that the course followed Willingham's (2008) call for a contextual basis to develop specific thinking forms. Moreover, with the outcomes of the research of Poh et al. (2010) in mind, regarding the intrapersonal traits, the course content seems to have caused 'neurological activity' within the students' brains.

The recommendation of this study for educators is to consider the competence construct of knowledge, skills and attitude (e.g. Campion et al., 2011; Delamare-Le Deist \& Winterton, 2005). Competent persons tend to possess the three elements of this construct. The course in this study offered the learning knowledge, skills and traits were facilitated, whereas regular classes focus only on knowledge and theory (Birou et al., 2016; Hoidn, 2017). This study illustrates how a construct is implemented and meant to inspire other educators and formalise soft skills learning objectives.

\section{FUTURE RESEARCH DIRECTIONS}

\section{Limitations and further research}

Indeed, the course might have caused 'neurological activity', i.e. some form of learning. The first limitation of this study is that it is questionable whether learning as 'ontogenetic adaption' occurred as meant by De Houwer et al. (2013, p. 633), who defined learning "as changes in the behavior of an organism that are the result of regularities in the environment of that organism".

The course consisted of three cohorts of only 95 students of an elective introduction course to PSM. Fifth, after getting information about the course's first lecture, a dozen students usually sign out for different reasons. Finally, in some cases, the required courses' timetables interfered with this elective course, and students expressed that they did not like the course design. Hence, only interested students stayed in the course after the introduction, which may be seen as a respondent's bias and probable convenience sampling.

The majority, 82 of the 95 students ( 86 per cent), has Dutch nationality, which might have caused cultural bias. Seventh, another potential limitation could be a socialdesirability bias, i.e. that (some) students might have anticipated and replied having developed (some) skills in the course and therefore replied differently in the second survey. However, as mentioned, the first survey's outcomes were not disclosed before filling out the second survey. 
Further research is suggested by replicating this study to test if the same results can be reached in other (cultural) circumstances. Moreover, it would be recommendable to distinguish in further research the most critical interpersonal and intrapersonal skills that lead to PSM success and replicate this study with a redesigned course and subsequent learning objectives.

The 'methodological toolbox' should not be restricted to a sheer observative, positivist research (Chicksand, Watson, Walker, Radnor, \& Johnston, 2012; Darby et al., 2019; Pettigrew, 2001); PSM and PSM educational research would benefit from active scholarly involvement in the complex challenges the field is facing regarding digitalisation and circularity.

\section{REFERENCES}

Ahmed, F., Fernando Capretz, L., Bouktif, S., \& Campbell, P. (2012). Soft skills requirements in software development jobs: a crosscultural empirical study. Journal of Systems and Information Technology, 14(1), 58-81.

Ammer, D. S. (1983). Purchasing and Materials Management for Health-Care Institutions. (Second and Revised Edition ed.). Lexington, Mass: Lexington Books.

Anderson, M. G., \& Katz, P. B. (1998). Strategic sourcing. The International Journal of Logistics Management, 9(1), 1-13.

Andrews, J., \& Higson, H. (2008). Graduate employability,' soft skills' versus 'hard' business knowledge: A European study. Higher education in Europe, 33(4), 411-422.

Anthony, E. M., \& Kadir, Z. A. (2012). A road not taken: a breakthrough in English for specific purposes via problem-based learning. Journal of Technical Education and Training, 4(1).

Bailly, F., \& Léné, A. (2013). The personification of the service labour process and the rise of soft skills: a French case study. Employee Relations.

Baily, P., Farmer, D., Crocker, B., Jessop, D., \& Jones, D. (2008). Procurement principles and management (10 ed.). Harlow: Pearson Education.

Bals, L., Schulze, H., Kelly, S., \& Stek, K. (2019). Purchasing and supply management (PSM) competencies: Current and future requirements. Journal of Purchasing and Supply Management, 25(5), 100572.

Bienhaus, F., \& Haddud, A. (2018). Procurement 4.0: factors influencing the digitisation of procurement and supply chains. Business Process Management Journal.

Biggs, J. B. (1996). Enhancing teaching through constructive alignment. Higher education, 32(3), 347-364.

Birou, L., Lutz, H., \& Zsidisin, G. A. (2016). Current state of the art and science: a survey of purchasing and supply management courses and teaching approaches. International Journal of Procurement Management, 9(1), 71-85.

Bonwell, C. C., \& Eison, J. A. (1991). Active Learning: Creating Excitement in the Classroom. 1991 ASHE-ERIC Higher Education Reports: ERIC.

Burt, D. N., Dobler, D. W., \& Starling, S. L. (2003). World class supply management: The key to supply chain management. Boston: McGraw-Hill Irwin.

Campbell, D. T., \& Stanley, J. C. (1966). Experimental and quasi-experimental designs for research. Dallas, Geneva, III., Hopewell, N.J., Palo Alto, London: Houghton Mifflin Company Boston.

Campion, M. A., Fink, A. A., Ruggeberg, B. J., Carr, L., Phillips, G. M., \& Odman, R. B. (2011). Doing competencies well: Best practices in competency modeling. Personnel Psychology, 64(1), 225-262.

Carr, A. S., \& Smeltzer, L. R. (2000). An empirical study of the relationships among purchasing skills and strategic purchasing, financial performance, and supplier responsiveness. Journal of Supply Chain Management, 36(3), 40.

Carter, C. R., Rogers, D. S., \& Choi, T. Y. (2015). Toward the theory of the supply chain. Journal of Supply Chain Management, 51(2), 89-97.

Carter, J. R., \& Narasimhan, R. (1996). Is purchasing really strategic? International Journal of Purchasing and Materials Management, 32(4), 20-28.

Cavinato, J. L. (1987). Purchasing performance: what makes the magic? Journal of Purchasing and Materials Management, 23(3), 1016.

Chamorro-Premuzic, T., Arteche, A., Bremner, A. J., Greven, C., \& Furnham, A. (2010). Soft skills in higher education: Importance and improvement ratings as a function of individual differences and academic performance. Educational Psychology, 30(2), 221-241.

Chicksand, D., Watson, G., Walker, H., Radnor, Z., \& Johnston, R. (2012). Theoretical perspectives in purchasing and supply chain management: an analysis of the literature. Supply Chain Management: An International Journal, 17(4), 454-472.

Cohen, J. (1988). The effect size index: $d$ (Vol. 2). New York: Lawrence Erlbaum Associates, Publishers.

Cousins, P. D., Lamming, R., Lawson, B., \& Squire, B. (2008). Strategic supply management: principles, theories and practice: Pearson Education.

Cousins, P. D., \& Spekman, R. (2003). Strategic supply and the management of inter-and intra-organisational relationships. Journal of Purchasing and Supply Management, 9(1), 19-29.

Cruz, C., \& Murphy, E. (1996). Purchasing's new importance requires a broader education. Purchasing, 12(9), 46-49.

Darby, J. L., Fugate, B. S., \& Murray, J. B. (2019). Interpretative research: a complementary approach to seeking knowledge in supply chain management. International Journal of Logistics Management.

De Houwer, J., Barnes-Holmes, D., \& Moors, A. (2013). What is learning? On the nature and merits of a functional definition of learning. Psychonomic bulletin \& review, 20(4), 631-642. 
Delamare-Le Deist, F., \& Winterton, J. (2005). What is competence? Human resource development international, 8(1), 27-46.

Dowd, K. O., \& Liedtka, J. (1994). What corporations seek in MBA hires: A survey. The Magazine of the Graduation management Admission Council, 2.

Drucker, P. F. (1977). People and performance: The best of Peter Drucker on management. New York: Harper \& Row, Publishers, Inc. Du Sautoy, M. (2019). The Creativity Code: Art and Innovation in the Age of Al. Cambridge, MA

London: Harvard University Press.

Dublin Descriptors, J. Q. I. (2004). Dublin descriptors. The Joint Quality Initiative Working document. Shared Dublin descriptors for the Bachelor's, Master's and Doctoral awards.

Durach, C. F., Kembro, J., \& Wieland, A. (2017). A new paradigm for systematic literature reviews in supply chain management. Journal of Supply Chain Management, 53(4), 67-85.

Eltantawy, R. A., Giunipero, L. C., \& Fox, G. L. (2009). A strategic skill based model of supplier integration and its effect on supply management performance. Industrial marketing management, 38(8), 925-936.

Erpenbeck, J., \& Scharnhorst, A. (2005). Modellierung von Kompetenzen im Licht der Selbstorganisation. In T. Meynhardt \& E. J. Brunner (Eds.), Selbstorganisation Managen - Beiträge zur Synergetik der Organisation. Münster, Deutschland: Waxmann Verlag $\mathrm{GmbH}$.

ESG Report. (2015). Standards and Guidelines for Quality Assurance in the European Higher Education Area (ESG). Retrieved from http://www.enqa.eu/index.php/home/esg/

Faes, W., Knight, L., \& Matthyssens, P. (2001). Buyer profiles: an empirical investigation of changing organizational requirements. European Journal of Purchasing \& Supply Management, 7(3), 197-208.

Fawcett, S. E., \& Rutner, S. M. (2014). A longitudinal view of supply chain education: Assessing the challenge of retaining relevance in today's dynamic marketplace. The International Journal of Logistics Management, 25(1), 180-201.

Feisel, E., Hartmann, E., \& Giunipero, L. C. (2011). The importance of the human aspect in the supply function: Strategies for developing PSM proficiency. Journal of Purchasing and Supply Management, 17(1), 54-67.

Field, A. (2009). Discovering statistics using SPSS (Vol. 3). Los Angeles, London: Sage publications.

Flöthmann, C., Hoberg, K., \& Wieland, A. (2018). Competency requirements of supply chain planners \& analysts and personal preferences of hiring managers. Supply Chain Management: An International Journal, in press.

Forrest, C. J., \& Swanton, T. (2021). Longitudinal associations between soft skills, education and labour market outcomes: evidence from a survey of young Australians. Education + Training, ahead-of-print(ahead-of-print). doi:10.1108/ET-10-2020-0325

Giunipero, L. C. (2000). A skills-based analysis of the world class purchaser (0945968434). Retrieved from Tempe, Arizona:

Giunipero, L. C., Denslow, D., \& Eltantawy, R. (2005). Purchasing/supply chain management flexibility: Moving to an entrepreneurial skill set. Industrial marketing management, 34(6), 602-613.

Giunipero, L. C., \& Handfield, R. B. (2004). Purchasing Education and Training II: CAPS Research Tempe, AZ.

Giunipero, L. C., Handfield, R. B., \& Eltantawy, R. (2006). Supply management's evolution: key skill sets for the supply manager of the future. International Journal of Operations \& Production Management, 26(7), 822-844.

Giunipero, L. C., \& Pearcy, D. H. (2000). World-class purchasing skills: an empirical investigation. Journal of Supply Chain Management, 36(3), 4-13.

Gross, H. (1966). Make or buy decisions in growing firms. The Accounting Review, 41(4), 745-753.

Hacking, I. (1984). Experimentation and scientific realism. In Science and the Quest for Reality (pp. 162-181): Springer.

Hannafin, M. J., \& Land, S. M. (2000). Technology and student-centered learning in higher education: Issues and practices. Journal of Computing in Higher Education, 12(1), 3-30.

Heckman, J. J., \& Kautz, T. (2012). Hard evidence on soft skills. Labour economics, 19(4), 451-464.

Heyse, V., Erpenbeck, J., \& Max, H. (2004). Kompetenzen erkennen, bilanzieren und entwickeln: Waxmann Verlag.

Hoidn, S. (2017). Student-centered learning environments in higher education classrooms. New York, NY: Palgrave Macmillan.

Jauch, L. R., \& Wilson, H. K. (1979). A strategic perspective for make or buy decisions. Long Range Planning, 12(6), 56-61.

Keough, M. (1993). Buying your way to the top. The McKinsey Quarterly, 1993(3), 41-63.

Kern, D., Moser, R., Sundaresan, N., \& Hartmann, E. (2011). Purchasing Competence: A Stakeholder-Based Framework for Chief Purchasing Officers. Journal of Business Logistics, 32(2), 122-138.

Killen, K. H., \& Kamauff, J. W. (1995). Managing purchasing: Making the supply team work. Homestead, IL: Irwin Publishing.

Kiratli, N., Rozemeijer, F., Hilken, T., de Ruyter, K., \& de Jong, A. (2016). Climate setting in sourcing teams: Developing a measurement scale for team creativity climate. Journal of Purchasing and Supply Management, 22(3), 196-204.

Knight, L., Meehan, J., Tapinos, E., Menzies, L., \& Pfeiffer, A. (2020). Researching the future of purchasing and supply management: The purpose and potential of scenarios. Journal of Purchasing and Supply Management, 100624. doi:https://doi.org/10.1016/j.pursup.2020.100624

Knight, L., Tu, Y.-H., \& Preston, J. (2014). Integrating skills profiling and purchasing portfolio management: An opportunity for building purchasing capability. International Journal of Production Economics, 147(2014), 271-283.

Kolchin, M. G., \& Giunipero, L. C. (1993). Purchasing education and training: Requirements and resources. Tempe, AZ: Center for Advanced Purchasing Studies.

Kruger, J., \& Dunning, D. (1999). Unskilled and unaware of it: how difficulties in recognizing one's own incompetence lead to inflated self-assessments. Journal of personality and social psychology, 77(6), 1121.

Laker, D. R., \& Powell, J. L. (2011). The differences between hard and soft skills and their relative impact on training transfer. Human Resource Development Quarterly, 22(1), 111-122.

Land, S., \& Hannafin, M. (2000). Student-Centered Learning Environments. In D. Jonassen \& S. Land (Eds.), Theoretical foundations of learning environments (pp. 1-24). Mahwah, NJ / London: Lawrence Erlbaum Associates, Inc. Publishers.

Leoni, R. (2014). Graduate employability and the development of competencies. The incomplete reform of the "Bologna Process". International Journal of Manpower, 35(4), 448-469.

Leuven/Louvain-la-Neuve Communiqué. (2009). The Bologna Process 2020: the European Higher Education Area in the new decade. Communiqué of the Conference of European Ministers Responsible for Higher Education, Leuven and Louvain-la-Neuve, 28-29 April. In.

Logan, J. (2011). The new Chinese city: globalization and market reform (Vol. 52): John Wiley \& Sons. 
Luzzini, D., \& Ronchi, S. (2016). Cinderella purchasing transformation: linking purchasing status to purchasing practices and business performance. Production Planning \& Control, 27(10), 787-796.

Masters, K. (2013). Edgar Dale's Pyramid of Learning in medical education: A literature review. Medical teacher, 35(11), e1584e1593.

McKeefry, H. (1998). Opportunity Knocks-Education and Technical Skills Will Open the Door to Lucrative Job Offers. CMP Net August, 3.

Mulder, M., Wesselink, R., \& Bruijstens, H. C. (2005). Job profile research for the purchasing profession. International Journal of Training and Development, 9(3), 185-204.

Muller, E. W. (2001). Report on the job analysis to update the certified purchasing manager and accredited purchasing practitioner examinations. Tempe, AZ: Center for Advanced Purchasing Studies.

Murphy, E. (1995). Half the battle is knowing what skills to acquire. Purchasing, 119(9), 49-54.

Mursion. (2021). From Skill to Instinct: How Higher Education Can Bridge the Gap Between Classroom and Career. Retrieved from San Francisco:

Narlikar, A. (2003). International Trade and Developing Countries: bargaining coalitions in the GATT \& WTO (Vol. 13): Taylor \& Francis.

Pagell, M., Das, A., Curkovic, S., \& Easton, L. (1996). Motivating the purchasing professional. Journal of Supply Chain Management, 32(3), 27.

Pettigrew, A. M. (2001). Management research after modernism. British journal of management, 12, S61-S70.

Poh, M.-Z., Swenson, N. C., \& Picard, R. W. (2010). A wearable sensor for unobtrusive, long-term assessment of electrodermal activity. IEEE transactions on Biomedical engineering, 57(5), 1243-1252.

Prahalad, C. K., \& Hamel, G. (1990). The core competence of the corporation. Harvard business review, 68(3), 79-91.

Sawilowsky, S. S. (2009). New Effect Size Rules of Thumb. Journal of Modern Applied Statistical Methods, 8(2), 26.

Schoenherr, T. (2010). Outsourcing decisions in global supply chains: an exploratory multi-country survey. International Journal of Production Research, 48(2), 343-378.

Scholten, K., \& Dubois, A. (2017). Advancing the skill set of SCM graduates-An active learning approach. International Journal of Operations \& Production Management, 37(11), 1683-1699.

Schulze, H., Bals, L., \& Johnsen, T. E. (2019). Individual competences for sustainable purchasing and supply management (SPSM) A literature and practice perspective. International Journal of Physical Distribution \& Logistics Management, in press.

Stek, K., \& Schiele, H. (2021). How to train supply managers - necessary and sufficient purchasing skills leading to success. Journal of Purchasing and Supply Management, in press, 100700. doi:https://doi.org/10.1016/j.pursup.2021.100700

Stinenbosch, M. (2017). Analysis of represented purchasing skills in academic literature and in current Dutch education provision. University of Twente,

Stinenbosch, M., \& Stek, K. (2017). The gap between academic purchasing education and the market needs. In-procurement, July / August, 24-25.

Tassabehji, R., \& Moorhouse, A. (2008). The changing role of procurement: Developing professional effectiveness. Journal of Purchasing and Supply Management, 14(1), 55-68.

Tatham, P., Wu, Y., Kovács, G., \& Butcher, T. (2017). Supply chain management skills to sense and seize opportunities. The International Journal of Logistics Management, 28(2), 266-289.

Trent, R. J., \& Monczka, R. M. (2003). Understanding integrated global sourcing. International Journal of Physical Distribution \& Logistics Management, 33(7), 607-629.

Tuononen, T., Parpala, A., \& Lindblom-Ylänne, S. (2019). Graduates' evaluations of usefulness of university education, and early career success-a longitudinal study of the transition to working life. Assessment \& Evaluation in Higher Education, 44(4), 581 595.

Van der Valk, W., Sumo, R., Dul, J., \& Schroeder, R. G. (2016). When are contracts and trust necessary for innovation in buyersupplier relationships? A necessary condition analysis. Journal of Purchasing and Supply Management, 22(4), $266-277$.

Von der Gracht, H., Giunipero, L. C., \& Schueller, M. (2016). Future-proof procurement; Now or never: the big procurement transformation. Retrieved from https://advisory.kpmg.us/articles/2017/future-proof-procurement.html

Von der Gracht, H., Huber-Straßer, A., Schueller, M., Müller, N., Lichtenau, P. E., \& Zühlke, H. (2018). Rethinking the value chain. A study on Al, humanoids and robots - Artificial Intelligence: Possible business application and development scenarios to 2040. Retrieved from https://assets.kpmg/content/dam/kpmg/xx/pdf/2018/09/rethinking-the-value-chain.pdf

Willingham, D. T. (2008). Critical thinking: Why is it so hard to teach? Arts Education Policy Review, 109(4), $21-32$.

Wong, C. Y., Grant, D. B., Allan, B., \& Jasiuvian, I. (2014). Logistics and supply chain education and jobs: a study of UK markets. The International Journal of Logistics Management, 25(3), 537-552.

Zawawi, N. A. W. A., Umar, A. A., Aziz, A. R. A., Crouzier, O., Khamidi, M. F., \& Idrus, A. (2014). PFI procurement skills: a cross-sector survey of practitioners. Procedia Engineering, 77, 170-178.

Zunk, B. M., \& Sadei, C. (2015). Sharpening the Industrial Engineering and Management qualification profile: Research findings from Austria. International Journal of Industrial Engineering and Management, 6(3), 109-120. Retrieved from https://www.scopus.com/inward/record.uri?eid=2-s2.084947928261\&partner|D=40\&md5=b0f42724b97636d4a62cfbdbc4defdd2

\section{ADDITIONAL READING}

Bals, L., Schulze, H., Kelly, S., \& Stek, K. (2019). Purchasing and supply management (PSM) competencies: Current and future requirements. Journal of Purchasing and Supply Management, 25(5), 100572.

Biggs, J. B. (1996). Enhancing teaching through constructive alignment. Higher education, 32(3), 347-364.

Du Sautoy, M. (2019). The Creativity Code: Art and Innovation in the Age of Al. Cambridge, MA London: Harvard University Press

Giunipero, L. C., \& Pearcy, D. H. (2000). World-class purchasing skills: an empirical investigation. Journal of Supply Chain Management, 36(3), 4-13.

Kiratli, N., Rozemeijer, F., Hilken, T., de Ruyter, K., \& de Jong, A. (2016). Climate setting in sourcing teams: Developing a measurement scale for team creativity climate. Journal of Purchasing and Supply Management, 22(3), 196-204 
Scholten, K., \& Dubois, A. (2017). Advancing the skill set of SCM graduates-An active learning approach. International Journal of Operations \& Production Management, 37(11), 1683-1699.

Stek, K., 2021. Personality Development in Higher Education in the Era of Industry 4.0 - Comparing educational practices and philosophies in Industry 1.0 and Industry 4.0, In: Olivas-Lujan, M., Bondarouk, T. (Ed.), Smart Industry - Better Management. Emerald Publishing, Bingley, West Yorkshire, England.

Stek, K., \& Schiele, H. (2021). How to train supply managers - necessary and sufficient purchasing skills leading to success. Journal of Purchasing and Supply Management, in press, 100700. doi:https://doi.org/10.1016/j.pursup.2021.100700

Von der Gracht, H., Giunipero, L. C., \& Schueller, M. (2016). Future-proof procurement; Now or never: the big procurement transformation. Retrieved from https://advisory.kpmg.us/articles/2017/future-proof-procurement.html

Willingham, D. T. (2008). Critical thinking: Why is it so hard to teach? Arts Education Policy Review, 109(4), $21-32$.

\section{KEY TERMS AND DEFINITIONS}

Globalisation: the process of purchasing on the worldwide market that has been promoted by the United Nations World Trade Organisation (WTO) and its predecessor, the General Agreement on Tariffs and Trades (GATT)

Hard Skills: knowledge and skills applicable for a specific job

Internet-of-Things: or machine-to-machine communication or the $4^{\text {th }}$ Industrial Revolution is the process of autonomic production systems

Procurement 4.0: the term for the implications of Industry 4.0 on the procurement function

Quasi-Experiment: an experiment with a single group with observations before and after without a control group.

Soft Skills: interpersonal or human-to-human skills and intrapersonal character traits

Student-Centred Approach: the student acquires knowledge, skills and attitudes through active, productive and effective learning

Teacher-Centred Approach: the teacher instructs students in a straight classical frontal fashion setting students in a passive, consuming role

\section{APPENDIX 1}

Table 3: PSM competences literature 1987-2020

\begin{tabular}{|c|c|}
\hline authors & methodology \\
\hline Anderson and Katz (1998) & Conceptual paper \\
\hline Baily, Farmer, Crocker, Jessop, and Jones (2008) & Qualitative, interview-based $(n=46)$ \\
\hline Bals et al. (2019) & Qualitative, interview-based $(n=46)$ \\
\hline Burt, Dobler, and Starling (2003) & PSM textbook \\
\hline Carr and Smeltzer (2000) & Quantitative, survey-based $(n=85)$ \\
\hline J. R. Carter and Narasimhan (1996) & Quantitative, survey-based $(n=302)$ \\
\hline Cavinato (1987) & Qualitative, interview-based $(n=50)$ \\
\hline Cousins and Spekman (2003) & $\begin{array}{l}\text { Mixed, interview-based }(n=23) \text { and survey-based } \\
(n=310)\end{array}$ \\
\hline Cruz and Murphy (1996) & Practitioners article \\
\hline Dowd and Liedtka (1994) & Quantitative, survey-based \\
\hline Eltantawy, Giunipero, and Fox (2009) & Quantitative, survey-based $(n=152)$ \\
\hline Faes, Knight, and Matthyssens (2001) & Quantitative, survey-based $(n=183)$ \\
\hline Flöthmann, Hoberg, and Wieland (2018) & Quantitative, survey-based $(n=243)$ \\
\hline Giunipero and Pearcy (2000) & $\begin{array}{l}\text { Mixed, interview-based }(n=23) \text { and survey-based } \\
(n=310)\end{array}$ \\
\hline Giunipero, Denslow, and Eltantawy (2005) & Mixed, interview-based $(n=41)$ and survey-based $(n=73)$ \\
\hline Giunipero and Handfield (2004) & Mixed, interview-based $(n=41)$ and survey-based $(n=73)$ \\
\hline Giunipero, Handfield, and Eltantawy (2006) & Qualitative, focus group meeting $(n=53)$ \\
\hline Kern, Moser, Sundaresan, and Hartmann (2011) & Quantitative, survey-based $(n=148)$ \\
\hline Keough (1993) & Conceptual paper \\
\hline Killen and Kamauff (1995) & PSM textbook \\
\hline Kolchin and Giunipero (1993) & Quantitative, survey-based $(n=131)$ \\
\hline McKeefry (1998) & Practitioners article \\
\hline Knight et al. (2014) & Quantitative, survey-based $(n=72)$ \\
\hline Mulder, Wesselink, and Bruijstens (2005) & Quantitative, survey-based $(n=261)$ \\
\hline Muller (2001) & Quantitative, survey-based $(n=2,416)$ \\
\hline Murphy (1995) & Practitioners article \\
\hline Pagell, Das, Curkovic, and Easton (1996) & Qualitative, interview-based $(n=14)$ \\
\hline Schulze, Bals, and Johnsen (2019) & Qualitative, interview-based $(n=46)$ \\
\hline Trent and Monczka (2003) & Quantitative, survey-based $(n=216)$ \\
\hline Tassabehji and Moorhouse (2008) & Qualitative, interview-based $(n=18)$ \\
\hline Tatham, Wu, Kovács, and Butcher (2017) & Quantitative, survey-based $(n=216)$ \\
\hline Zawawi et al. (2014) & Quantitative, survey-based $(n=43)$ \\
\hline
\end{tabular}




\section{APPENDIX 2}

Table 4: Rankings of the items in the two student surveys

\begin{tabular}{|c|c|c|c|c|c|}
\hline & \multirow{2}{*}{$\begin{array}{c}\text { Mean } \\
\mathrm{O}_{1}\end{array}$} & \multicolumn{3}{|c|}{ Mean } \\
\hline & & & $\delta$ & $\mathrm{O}_{2}$ & $\delta$ \\
\hline 1 & Loyalty - Being loyal in professional life & 3.69 & .813 & 3.74 & .829 \\
\hline 2 & Honesty - Being trustworthy in professional life & 3.67 & .706 & 3.77 & .739 \\
\hline 3 & $\begin{array}{l}\text { Conscientiousness - Conscientiousness implies a desire to do a task well and to } \\
\text { take obligations to others seriously }\end{array}$ & 3.38 & .776 & 3.50 & .874 \\
\hline 4 & Result-orientated action-taking - Aiming on effectiveness & 3.34 & .738 & 3.47 & .813 \\
\hline 5 & Capacity to be empathetic - Capacity to listen and understand & 3.32 & .741 & 3.66 & .769 \\
\hline 6 & Social Manners - Being tactful, diplomatic and having organisational sensitivity & 3.21 & .849 & 3.32 & .806 \\
\hline 7 & Ability to Resolve Conflicts - Being able to avoid and resolve conflicts & 3.17 & .808 & 3.27 & .894 \\
\hline 8 & Teamwork - Being able to work in a group of persons, acting together as a team & 3.15 & .755 & 3.47 & .755 \\
\hline 9 & $\begin{array}{l}\text { Critical thinking - Having the skills and knowledge of how to assess problems or } \\
\text { issues in a critical manner }\end{array}$ & 3.14 & .819 & 3.25 & .837 \\
\hline 10 & $\begin{array}{l}\text { Willingness to Learn - Being professionally curious, motivation to learn } \\
\text { continuously }\end{array}$ & 3.13 & .775 & 3.27 & .764 \\
\hline 11 & Ability to Solve Problems - Being able to solve problems in a systematic way & 3.11 & .722 & 3.38 & .705 \\
\hline 12 & $\begin{array}{l}\text { Task management (priority management) - Being able to make a prioritisation in } \\
\text { business-related tasks }\end{array}$ & 3.06 & .882 & 3.28 & .745 \\
\hline 13 & Communication skills - Having the skills and knowledge of how to communicate & 2.98 & .825 & 3.34 & .849 \\
\hline 14 & Capacity to Advice - Having consultancy skills & 2.96 & .886 & 3.16 & .766 \\
\hline 15 & $\begin{array}{l}\text { Inter-generation ability - Being aware of and able to work with people from } \\
\text { different generations }\end{array}$ & 2.95 & .909 & 3.09 & .988 \\
\hline 16 & $\begin{array}{l}\text { Comprehension of Complexity - Being able to understand and solve complex } \\
\text { problems }\end{array}$ & 2.95 & .674 & 3.19 & .692 \\
\hline 17 & Self-assurance - Being assertive and having self esteem & 2.94 & .783 & 3.05 & .872 \\
\hline 18 & $\begin{array}{l}\text { Cross-cultural awareness - The ability to become aware of cultural values, beliefs } \\
\text { and perceptions of yourself and other cultures }\end{array}$ & 2.88 & .955 & 3.12 & .914 \\
\hline 19 & $\begin{array}{l}\text { Holistic Thinking - Holistic thinking involves understanding a system by sensing its } \\
\text { large-scale patterns and reacting to them }\end{array}$ & 2.87 & .640 & 3.02 & .747 \\
\hline 20 & Poise - Being (self) confident & 2.87 & .802 & 3.03 & .822 \\
\hline 21 & $\begin{array}{l}\text { Proactivity - Being anticipatory, change-oriented and self-initiated behaviour in } \\
\text { situations }\end{array}$ & 2.87 & .789 & 3.10 & .804 \\
\hline 22 & Customer-oriented - being oriented on the end user & 2.86 & .766 & 3.06 & .814 \\
\hline 23 & $\begin{array}{l}\text { Cross-functional management - Being able to work with people from other } \\
\text { professions and functions }\end{array}$ & 2.86 & .704 & 3.23 & .707 \\
\hline 24 & Decision Making - Being able to make decisions & 2.83 & .767 & 3.16 & .807 \\
\hline 25 & $\begin{array}{l}\text { Stress management - Know how to manage stress at home and work using a } \\
\text { variety of techniques }\end{array}$ & 2.83 & .977 & 3.14 & .833 \\
\hline 26 & $\begin{array}{l}\text { Flexibility and agility - Being able to adjust one's behaviour to new information or } \\
\text { changing circumstances }\end{array}$ & 2.79 & .742 & 3.07 & .737 \\
\hline 27 & Willingness to take risks - Taking well-considered risks & 2.73 & .805 & 2.94 & .773 \\
\hline 28 & Persistence - Continuing in an opinion or course of action despite opposition & 2.70 & .829 & 3.04 & .738 \\
\hline 29 & $\begin{array}{l}\text { Strategic Thinking - Strategic thinking is a process that defines how people think } \\
\text { about, assess, view, and create the future for themselves and others }\end{array}$ & 2.70 & .829 & 3.21 & .780 \\
\hline 30 & Power of Persuasion - Having influential skills & 2.66 & .721 & 2.80 & .699 \\
\hline 31 & Creativity - Being creative in professional life / having creative ideas & 2.60 & .880 & 2.83 & .771 \\
\hline 32 & Inventiveness - Being able to convert creative ideas in practice & 2.58 & .752 & 2.86 & .756 \\
\hline 33 & Leadership/community management - Being able to manage employees in teams & 2.51 & .812 & 2.89 & .819 \\
\hline 34 & Networking / Building Relations - Networking and relations management & 2.49 & .836 & 2.86 & .863 \\
\hline 35 & Salesperson skills - Having acquisition strength and having canvassing ability & 2.36 & .883 & 2.80 & .942 \\
\hline 36 & $\begin{array}{l}\text { Negotiation skills - Being able to negotiate the specific commercial and legal } \\
\text { terms in a contract needed to be settled in a satisfactory way }\end{array}$ & 2.21 & .825 & 2.71 & .780 \\
\hline
\end{tabular}

Notes: $O_{1}$ is the first survey held in the first week of the course; $O_{2}$ is the second survey taken after the course; the items were measured on a 5-point Likert scale -fully disagree (1) to fully agree (5). The items are derived from Stek and Schiele (2021). 